\title{
Bar Model: A Beneficial Tool in Learning Percentage
}

\author{
Herani Tri Lestiana ${ }^{1^{*}}$, Cici Tri Wanita ${ }^{2}$ \\ 1 IAIN Syekh Nurjati, West Java, 45131, Indonesia \\ 2 Yayasan Inspirasi, DKI Jakarta, Indonesia \\ *Corresponding author: IAIN Syekh Nurjati, Cirebon, West Java, 45131, Indonesia. e-mail addresses: $\underline{\text { h.t.lestiana@gmail.com }}$
}

\section{a r t i c l e i n f o}

How to cite this article:

Lestiana, H.T., \& Wanita, C.T. (2019). Bar Model: A Beneficial Tool in Learning

Percentage, 8(2), 1 - 10.

doi:http://dx.doi.org/10.24235/eduma.v8i2.5392

Article history:

Received: 1031,2019

Accepted: 12 05, 2019

Published: 12 05, 2019

Copyright (C) 2019 by author (s) and EduMa: Mathematics Education Learning and Teaching under the Creative Commons Attribution-ShareAlike 4.0 International License.

\section{a b s t r a c t}

Bar Model: A Beneficial Tool in Learning Percentage. Percentage is found to be a familiar and challenging topic at the same time. Percentage has many application in daily life, yet many students still find it difficult. It might because many schools teach merely a formal procedure and pay less attention to the understanding of the reasoning behinds percentage ideas. This small study employed a design research and aimed at supporting students in understanding percentage by using bar model. Eleven 6th and 7th grade students of American International School of Rotterdam were participated in this study. A sequence of learning activities was designed to help students construct their understanding of percentage. The activities consisted of some rich contextual problems that lead to the emergence of bar model. The result revealed that the model can help students construct students' knowledge of the relation among numbers in percentage, and also help them solve percentage problems systematically through some intermediate steps which include benchmarks.

\section{Keyword s :}

Design Research; Contextual; Tool 


\section{INTRODUCTION}

The topic of percentage is an essential topic in mathematics and can be found widely in daily life. The context of discount, nutrition facts in a food label, and statistical data are examples involving percentages. Therefore, it is important for students to have a strong understanding of the idea of percentage. However, many teachers in many schools often merely provide formal algorithms for students to work with percentage without building their sense and understanding of percentage (Heuvel-Panhuizen, 2003; Ningtyas, 2016; Rianasari, Budayasa, \& Patahuddin, 2012; Sarumaha, Putri, \& Hartono, 2018). Students might be able to solve percentage problems by using such algorithm, but they do not understand the reasoning behinds it. Moreover, students might apply the algorithm to all percentage problems without understanding what is asked and what is needed. Hence, it can lead students to incorrect process.

In addition, some studies showed that many students still find it challenging and difficult to understand the idea of percentage and to solve related problems (Hawera \& Taylor, 2011; Heuvel-Panhuizen, 2003; Ningtyas, 2016; Reys, R., Lindquist, M. M., Lambdin, D.V. \& Smith \& L., 2007; Rianasari et al., 2012; Van Galen \& Van Eerde, 2013). This issue might due to some causes. Firstly, the concept of percentage comprises several ideas, such as percentage as a part of a whole and percentage represents a proportion of two numbers or quantities (Hawera \& Taylor, 2011). Secondly, some students have difficulties in applying percentage concept in contextual problems.

By using bar model, students can see relationship between the percentage and the value. According to Van Galen \& Van Eerde (2013), a bar model is a fruitful model to support students' flexible mental arithmetic with percentages. Thus, it is expected that percentage bar can help students construct their understanding of percentage in this study.

To deal with this issue, this study was conducted to investigate how to promote students' understanding of percentage. The question of this study is: "How can bar models support students' understanding of percentage?".

\section{THEORETICAL FRAMEWORKS}

\section{Percentage}

Percentage comprises various ideas. Firstly, it describes a relation of a part of a whole. In this case, the whole is $100 \%$. Secondly, percentage illustrates a proportion of two numbers or quantities. Merely focusing on part-whole idea of percentage might bring difficulties for students when it comes to a percentage greater than 100\% (Parker \& Leinhardt, 1995). Understanding the idea of fraction, decimal, and ratio is also needed to build a comprehensive insight about percent as those ideas are corelated each other (Reys, R., Lindquist, M. M., Lambdin, D.V. \& Smith \& L., 2007; van Galen et al., 2008).

\section{Bar Model}

Understanding percentage means connecting new and existing knowledge; concept and its representations; concept and its application in everyday life (Mousley in Ningtyas, 2014). Utilizing models in math classroom can help students construct their knowledge by connecting concrete ideas and formal ideas (Heuvel-Panhuizen, 2003). An example of adventageous model is bar model. Bar model can provide a clear illustration of what is given and what is asked in the problems (Van Galen \& Van Eerde, 2013). The area of bar model represents the concept of "a whole" so it make students easier to understand the concept of percentage as a part of a whole (van Galen et al., 2008). Moreover, bar model also gives opportunity for students to be aware of the relation among numbers and to do some intermediate steps in solving problems so it can show clearly students' thinking process (Van Galen \& Van Eerde, 2013).

To lead the emergence of models, teachers need to create a rich and accessible context (Ahmed in Hawera \& Taylor, 2011). The rich task and context should be able to stimulate the rise of a model so the model can function as the model of the problem. For example, in the context of chocolate bar, the picture of chocolate bar can function as model of the context. Model of the problem can transform to model for the problem and can be used to wider range of problems. For instance, the picture of chocolate bar can be represented into bar model. 


\section{METHODS}

To answer the research question, a sequence of learning activities need to be designed. Thus, this study employed a design research. The aim of design research is to develop a local instructional theory that correlates some theories (related to math topics, models, and the approach) and the implementation of the theories. In other words, design research tries to balance theories and practices in order to develop a grounded theory about instructional activities that can support students' understanding (Bakker \& van Eerde, 2015).

Design research consists of three steps, namely preparation, classroom experiment, and retrospective analysis. In the preparation, data about students' initial understanding and starting point were collected as consideration in developing learning materials and Hypothetical Learning Trajectory (HLT). The HLT functions as a guideline for teachers in conducting the teaching experiment. After the experiment, the HLT is used in the retrospective analysis, to compare the theorybased conjectures and actual students' thinking.

This article focuses on the first lesson which pointed out on the use of a percentage bar to support students' solving percentage problems through systematically reasoning.

\section{a. Participants}

This study was conducted in American International School of Rotterdam. There were eleven of 6th and 7 th grade students involved in this study. They were grouped into 5 groups. This article focused on a group consisting three students, namely Theo, Ceres, and Skyler. Theo's response and works were elaborated more in some parts.

\section{b. Data Collection}

\section{Preparation (written test and interview)}

Before carrying out the teaching experiment, a written test and an interview were conducted to identify students' procedures in solving percentage problems and to explore more information about their initial understanding of percentage. During the interview, the students are asked to re-solve some problems in the written test and are asked some questions to encourage their reasoning and explanation towards their solutions. From the interview, the researcher got interview data and students' work.

\section{Teaching experiment}

Three weeks after the interview, the lesson activities were carried out. The aim of the first lesson was to investigate how a percentage bar supports students in constructing their knowledge of percentage. During the lessons, a video registration and students' works were collected.

\section{c. Hypothetical Learning Trajectory (HLT)}

\section{Starting Point}

In the regular class, the teacher has asked the students to make a scheme about the relation among fractions, percentages, and decimals. In general, the students notice the idea of percentage as something over a hundred. Moreover, they also can relate familiar fractions, such as $1 / 2,1 / 4$, and $3 / 4$ to percentages form, and vice versa.

\section{Mathematical Goals}

The lesson were designed by considering students' starting points from the result of the written test and the interview. The mathematical goals of the learning activities were:

- Students are able to use a percentage bar for determining the value of given percentage from the total value.

- Students are able to use a percentage bar for determining the total value of the given percentage.

\section{Instructional Activities}

\section{First Problem}

The learning sequences started with a context of road construction as below.

Four-hundred-meters length road has to be repaired. However, the workers have just finished $10 \%$ of the road. Determine the length of the road that has been finished by making a drawing of the road and using it to solve the problem.

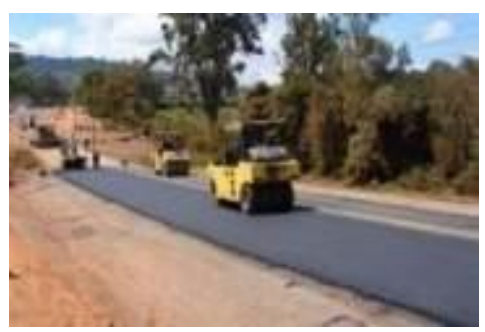

Figure 1. Illustration of road construction problem 
The teacher gave an opportunity for the students to figure out the answer. The aim of this activity was to guide the students to emerge with the notion of the percentage bar by illustrating the road as a bar. Next, the teacher asked the students to find the length of the road that has been finished if the workers just finished $5 \%$ and $1 \%$. After finishing the given problem, the students together with the teacher discussed the answer. Thereafter, the students got the next problem, in which they have to determine the length of the road that has been finished if the workers have just finished $15 \%$ and $17 \%$ of the total length of the road.

\section{Conjectures of students' thinking}

1. The students have sense that 40 is $10 \%$ of 400

2. Divide the whole value by the percentage, for example, to find the value of $5 \%$ they divide 400 by 5 .

3. Without relating it to the bar, students may multiply the whole value by the percentage. For instance, to find the value of $15 \%$ they multiply 15 by 400 and then divide it by 100 .

4. Do an incorrect procedure (incorrect additive reasoning) in finding the corresponding value of the percentage. For example, to get the value of $17 \%$, they add the value of $1 \%$ by 16 .

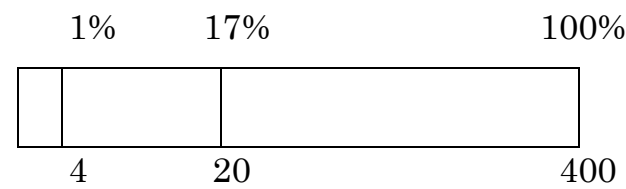

5. Use a particular percentage as the anchor point to get the value of intended percentage.

For example, students find the value of Open Access viding the value of $10 \%$ by 10 .

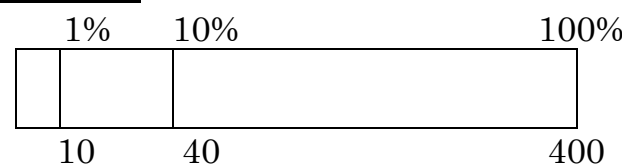

Response of the teacher towards students' thinking

1. If the students use the percentage bar and do a correct procedure, then the teacher may ask their reasoning and provide more challenging problems to develop students' understanding of the use of percentage bar in solving the percentage problems, for example:
- Why do you divide 100\% by 20 to get the corresponding value of $5 \%$ ?

- If the total length of the road is $800 \mathrm{~m}$ and the workers just finished $37 \%$ of the road, then how many meters of the road that has not been finished?

2. If the students have an incorrect calculation by dividing the total length of the road with the percentage, then the teacher may ask the students to illustrate the problem by drawing the road and utilize it as a percentage bar. For example, could you illustrate the situation by drawing the road and marking the position of the road that has been finished? It aims at making the students realize the logical sequence in solving the problem and perceive the percentage number as a part of hundred percent instead of just a usual number.

3. If the students do an incorrect procedure (incorrect additive reasoning) in finding the corresponding value of the percentage, for example, to get the value of $17 \%$, they add the value of $1 \%$ by 16 , the teacher may ask the students about their understanding of percentage. Since the students already perceived percentage as a part of hundred, then the teacher could give a follow-up question, for example could you tell me the value of $10 \%$ of 400 ? Now, look at your answer and tell me what you think about the length of $1 \%$ and $17 \%$.

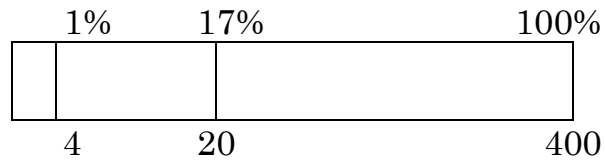

\section{Second Problem}

After discussing the road construction problem, the teacher posed a new problem about discount:

Angel wants to buy a pair of shoes. She gets $15 \%$ discount of the normal price. The shopkeeper tells that the discount equals $€ 12$. How much is the normal price?

This problem aimed at knowing whether the students can use the percentage bar to figure out the whole from the part and to solve other percentages problems. 
Conjectures of students' thinking:

1. Students multiply $15 \%$ by $€ 12$ or divide 12 by $15 \%$ to get the normal price.

2. Without or by using a bar, students use the notion of ratio. For instance, firstly they find the value of $5 \%$, and then multiply it by 20 to get $100 \%$. Or, after getting the value of $5 \%$, they might use the idea of doubling to get $100 \%$.

Response of the teacher towards students' thinking

1. If students multiply $15 \%$ with $€ 12$ or divide 12 by $15 \%$, the teacher can encourage students to notice what is known and what is asked in the problem.

2. If pupils already use the notion of ratio, the teacher engages pupils to translate their solutions into a bar model.

\section{RESULT AND DISCUSSION}

\section{Written Test and Interview}

In the written test, the students are asked to solve 15 problems related to perceentage with various level of difficulties.

A week after the written test, the students were asked to re-do three problems in the written test and were interviewed to figure out their understanding about percentage and their solution of some problems in the written test. The written test and interview showed that students could relate particular percentages and fractions, and vice versa. A sample of Theo's answer in Figure 2 and the transcript of the interview below revealed that he knew that $\frac{3}{4}$ is equal to $75 \%$, and $\frac{1}{4}$ is equal to $25 \%$.

6) What percentage of the children in class 5 is a member of a sports club?

Result sports questionnaire

for: class 5

Are you a member of a

sports club?

yes: $\mathrm{HH} H \mathrm{HH} H \mathrm{HH}$

no: $H$ Ht

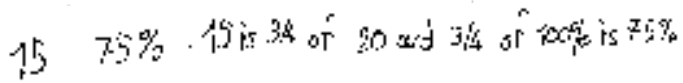

$5 \quad 25 \%$
Figure 2. Theo's solution on problem number 6 in the interview

\begin{tabular}{|c|c|}
\hline Teacher & $\begin{array}{l}\text { How do you start? What the } \\
\text { problem asking you? }\end{array}$ \\
\hline Theo & $\begin{array}{l}\text { Ah..I know..Because, this is a } \\
\text { quarter of the class (pointing } \\
\text { 15), and three quarter of one } \\
\text { hundred is seventy five. }\end{array}$ \\
\hline Teacher & $\begin{array}{l}\text { Why do you relate it to one } \\
\text { hundred? }\end{array}$ \\
\hline Theo & $\begin{array}{l}\text { Because the maximum of } \\
\text { percentages. }\end{array}$ \\
\hline
\end{tabular}

In problem 9 as shown in Figure 3, Theo explained that he had a 'technique', a kind of a formal algorithm, to find a value of particular percentage from a whole unit. He multiplied the whole value with the percentage and then divided it by a hundred. For example, in problem 9 , to get the value of $15 \%$ discount, he multiplied $15 \%$ with $€ 600$ and then divided it by a hundred. Figure 3 and the transcript of the interview below show how Theo solved the problem by using the 'technique'.

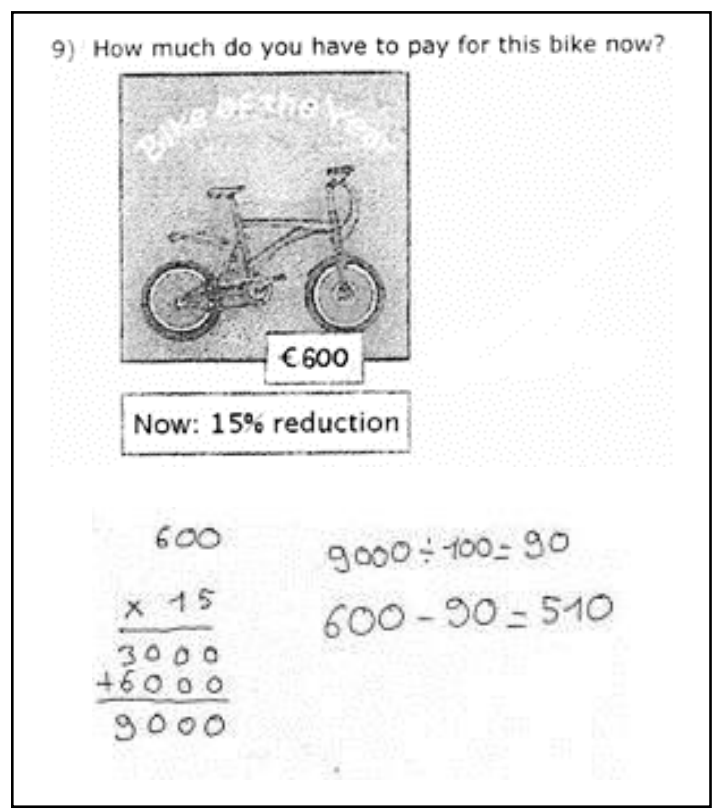

Figure 3. Theo's solution on problem number 9 in the interview

\begin{tabular}{|ll|}
\hline Theo & $:$ I multiply six hundreds by \\
fifteen & \\
Teacher & : Why? \\
Theo & $\begin{array}{l}\text { : Because I have a technique but I } \\
\text { don't have a ... I don't know how }\end{array}$ \\
& $\begin{array}{l}\text { I can explain } \\
\text { Teacher }\end{array}$ \\
$\begin{array}{l}\text { : So, in your school in France, your } \\
\text { teacher told you about this }\end{array}$
\end{tabular}




\begin{tabular}{|ll|}
\hline Theo & technique? \\
& : Yes (continuing his counting) \\
Teacher & Nine zero zero zero divided by \\
one hundred & : Why should you divided by one \\
hundred? & \\
Theo & because it's one hundred percent. \\
& (writing down his solution in the \\
& paper) equal 90. And after, 90 is \\
& 15\% of this (pointing 600), and \\
& I..(while writing) six hundreds \\
& minus (writing 90 in his paper) \\
& equals (writing 510 in his \\
paper). & Why did you subtract this \\
Teacher & (pointing his work) \\
Theo & Because it's (pointing 90) fifteen \\
& percents and it's a reduction.
\end{tabular}

The result of the written test and the interview showed that the two students, Theo and Ceres, had difficulties in finding the whole value of a given percentage, such as finding the normal price if $30 \%$ discount is 42 . The picture below showed how Theo struggled with such problem.

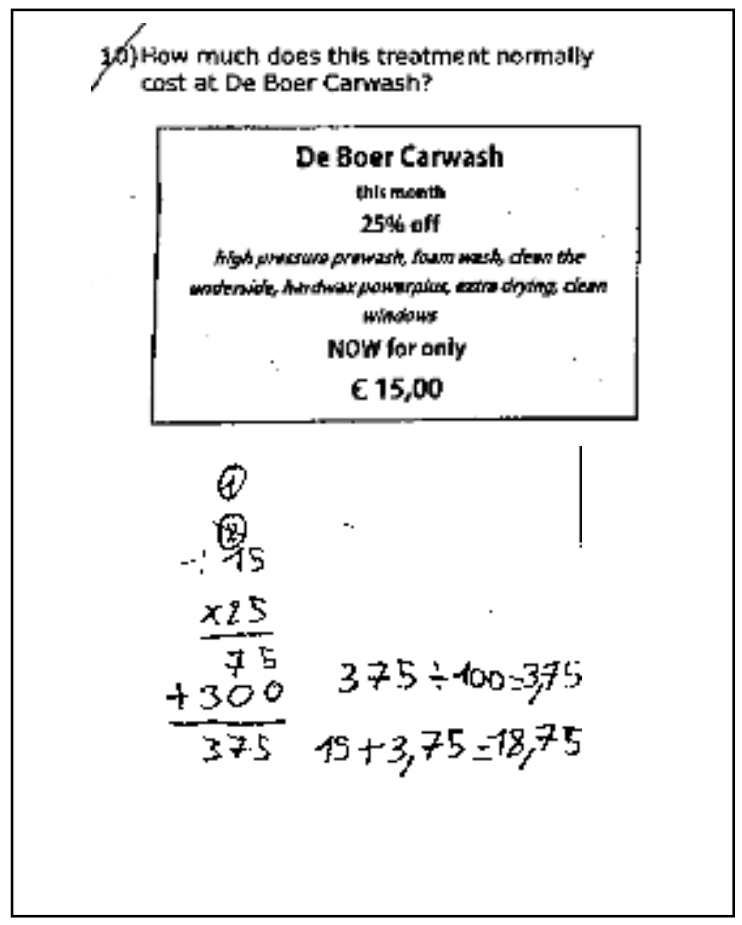

Figure 4. Sample of Theo's work in written test

In the picture above, the student (Theo) applied the formal procedure in a wrong way, without noticing what is known and what is asked. Theo kept using the procedure he knew, in which he multiplied the percentage with the other number in the problem, yet actually the procedure did not hold in the problem.

In the interview, Theo was asked to re-solve the problem above. The transcript below showed that Theo was aware of in what situation he could apply the technique (formal procedure).

Teacher: $\begin{gathered}\text { Can you repeat your } \\ \text { explanation? }\end{gathered}$

Theo : We need to add twenty five percents to that (pointing $€ 15.00$ ) but it's difficult because the twenty five percents is the twenty five percents of the last price before this (pointing $€ 15.00$ ) and we don't know the last price. It's like we don't know how much is twenty five percents. If I do the technique, it's wrong because I take $25 \%$ of here. (Thinking for a long time)

Teacher : I'll give more examples. Let this is bread (drawing bread in the paper). You get $25 \%$ discounts, and now the price is 30. Can you figure out the normal price?

Theo : Yes, forty.

Teacher : Why?

Theo : Because it's forty, we can divide it by four. From forty, we subtract $25 \%$, for ten, $25 \%$ of forty, and we..forty minus ten is thirty.

Teacher : Can you figure out something to solve this problem?

Theo : Yes. (thinking for a while) Eighty.

Teacher : Eighty? Do you think so? Why?

Theo : Because we can.. fifteen times two (pointing 30). If the price before this is forty, we can times two. Oh no, twenty.

Teacher : Why?

Theo : Because twenty we can divide it by four, and four is five, and we take one of this five, because it's one quarter (pointing 25\%) and the twenty minus five equals fifteen.

In the transcript above, Theo struggled to figure out how to solve the problem in which he could not apply the technique eventhough he understood what the problem was about. After being stimulated with a more simple 
problem, Theo started to notice how to solve such problem.

This kind of problem can be solved easily if students use anchor points or benchmarks as the intermediate steps. Therefore, in the learning activities, the use of percentages bar was introduced through contexts of road construction and discount.

\section{First Problem}

At the beginning of the lesson, the students were asked to determine the value of $10 \%, 5 \%$, $1 \%, 15 \%$, and $17 \%$ of 400 respectively. In this problem, firstly Theo found the $10 \%$ by using the ratio table as shown in Figure 5(a). Then, as had been predicted in the HLT, he was able to figure out how to find $5 \%, 1 \%, 15 \%$, and $17 \%$ by relating to previous numbers or using a benchmark. For example, as revealed in the transcript below, he got $15 \%$ of 400 meters by adding the value of $10 \%$ and $5 \%$.

Teacher : Can you show me how you get the $15 \%$ ?

Theo : You just add five plus ten percents and you add twenty meters plus forty meters, equals sixty meters.

Figure 5(b) and Figure 5(c) below shows how Theo found the value of $15 \%$ and $17 \%$ of 400 meters respectively using bar model.

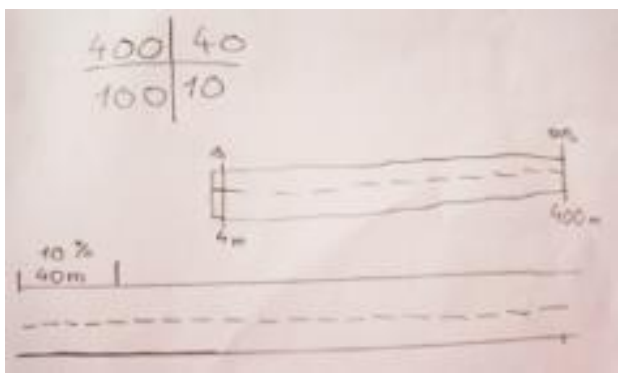

(a)

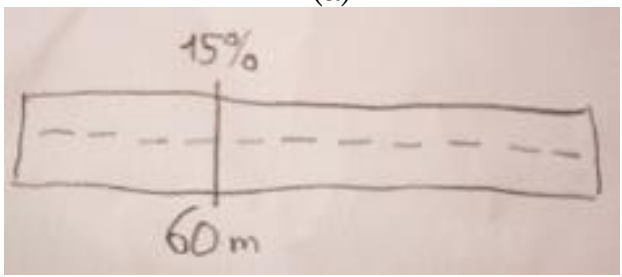

(b)

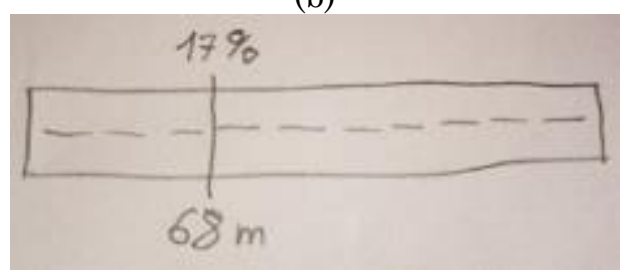

(c)
Figure 5. Theo's works on the first problem

\section{Second Problem}

For the second problem, the students had to find the normal price if $15 \%$ discount is equal to $€ 12$. In the beginning, Theo misunderstood the problem, in which he thought that $€ 12$ is the price after the discount. Hence, in the beginning he could not figure out the problem. However, after a long discussion with the other students, he could tackle the problem as can be seen in Figure 6 (the green writing). In solving the problem, firstly, he tried to find the value of $5 \%$ by dividing the value of $15 \%$ by three, and he got the value of $5 \%$ is $€ 4$. He knew that to get $100 \%$ he needed to multiply the $5 \%$ by 20 . To get the corresponding value, he also multiplied $€ 4$ by 20 . However, he did not draw a bar in solving this problem. This solution corresponded to one of the conjectures of students' thinking in the HLT.

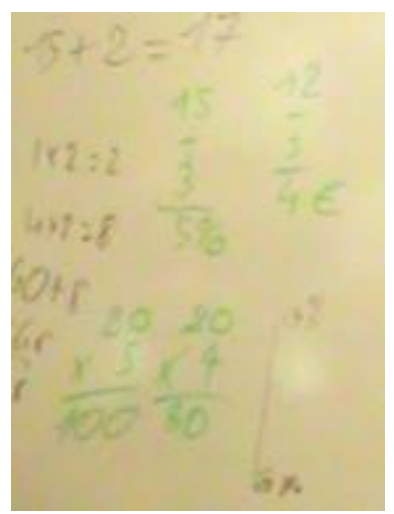

Figure 6. Theo's work on the second problem.

After the students presented how they solved the second problem, their strategies were translated into a bar to show them how to work in a bar in solving the problem (Figure 7).

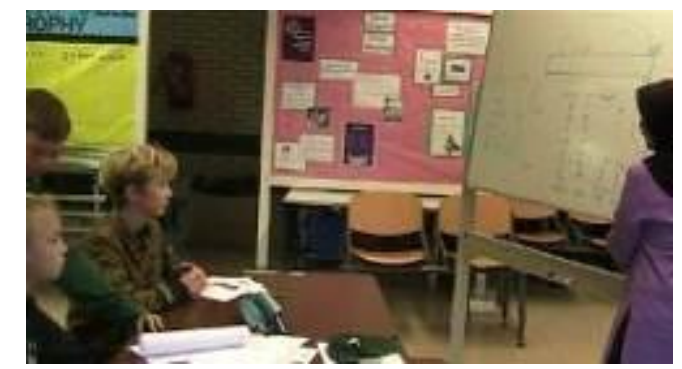

Figure 7. Representation of percentages bar

\section{Third Problem}

Before ending the lesson, the students were asked to solve an additional problem to confirm their' understanding of bar model and the reasoning behinds it. The teacher asked 
students to find the value of $100 \%$ if the value of $35 \%$ is equal to $€ 28$.

The transcript below showed the conversation between the teacher and the students regarding the additional problem.

\begin{tabular}{|c|c|}
\hline Ceres & $\begin{array}{l}\text { : (asking the teacher) what about } \\
\text { getting it into forty and then } \\
\text { minus a half (of forty)? }\end{array}$ \\
\hline Teacher & $\begin{array}{l}\text { Yes, you can use it. } \\
\text { (Theo was writing on his paper, } \\
\text { Skyler was thinking) After few } \\
\text { seconds, }\end{array}$ \\
\hline Theo & $\begin{array}{l}\text { (whispering while he wrote on } \\
\text { his paper) I know that, ooohh.. } \\
\text { (whispering) it's a five percents } \\
\text { (Ceres and Theo was writing on } \\
\text { his paper, Skyler was still } \\
\text { thinking, and the teacher looked } \\
\text { at students' works) }\end{array}$ \\
\hline Skyler & $\begin{array}{l}\text { : (whispering while thinking) } \\
\text { Ehhmm.. so.. }\end{array}$ \\
\hline Theo & $\begin{array}{l}\text { : (whispering while writing on his } \\
\text { paper) Wait..No..it's four..and } \\
\text { then.. }\end{array}$ \\
\hline Teacher & $\begin{array}{l}\text { : How to get one hundred } \\
\text { percents? }\end{array}$ \\
\hline Theo & : It's the same, it's eighty. \\
\hline Skyler & $\begin{array}{l}\text { How is that eighty? } \\
\text { (Ceres was still writing on his } \\
\text { paper) }\end{array}$ \\
\hline Theo & : Yes, it's eighty. \\
\hline Teacher & : Why? \\
\hline Theo & $\begin{array}{l}\text { : (while taking his paper up and } \\
\text { showing his work to the teacher } \\
\text { on Figure } 8 \text { ) } \\
\text { Because I divide it by seven, here } \\
\text { is five (pointing how he divided } \\
35 \% \text { by seven) and I divide it by } \\
\text { seven, it's four (pointing how he } \\
\text { divided } 28 \text { by seven). Then I } \\
\text { multiply this (pointing } 5 \% \text { ) by } \\
\text { twenty, equals one hundred, and } \\
\text { this (pointing 4) by twenty for } \\
\text { eighty. } \\
\text { (Skyler was listening to Theo's } \\
\text { explanation, and Ceres was still } \\
\text { writing struggling with his } \\
\text { answer) }\end{array}$ \\
\hline
\end{tabular}

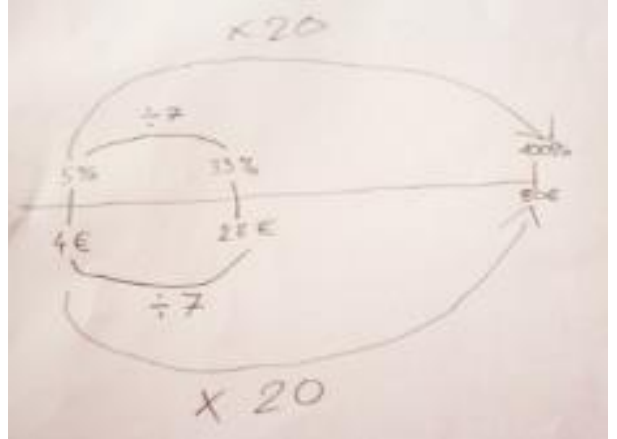

Figure 8. Theo's thinking process on the third problem

In conversation, Theo thought that the answer is eighty. However, he re-thought it and drew a double number line in his paper. Thereafter, he tried to find the value of $5 \%$ by dividing the value of $35 \%$ by seven, and he got the value of $5 \%$ is $€ 4$. He knew that to get $100 \%$ he needed to multiply the $5 \%$ by 20 . To get the corresponding value, he also multiplied $€ 4$ by 20 . In the end, he got $€ 80$ as the final answer. This solution is corresponding to the predictions of students' answer in the HLT.

The fragment indicated that Theo can see the relationship among numbers. Moreover, Theo started showing his flexible mental arithmetic. $\mathrm{He}$ was able to find the value of other percentages by using benchmarks or anchor points as the intermediate steps. For example, in the last problem, he knew that to get $100 \%$, he should multiply $5 \%$ by twenty. The previous problems (road construction and discount problem) seemed to give an impression on him in solving the last problem. He might find that $35 \%$ and $€ 28$ are divisible by 7 (common divisor) since in the previous problem he used $5 \%$ as the benchmark. Thus, he tried to find a number that can divide $35 \%$ to get $5 \%$.

The conversation fragment and Theo's works indicated that he understood how to use a percentages bar to determine the value of given percentage of the total value (as in the first problem), and to determine the total value of the given percentage (as in the second problem). In the first problem, Theo began to notice how to use anchor points as intermediate steps in a percentage bar to find the value of other percentages. He also used anchor points to solve the second problem eventhough he did not present it in a bar. In the last problem, after the teacher shows students how to use a bar and translates students' strategies into the bar, Theo can solve the last problem by using a double 
number line. It is presumed that Theo thought that the line is similar, analog and has the same function with a bar, so he unconsciously draws that line, not a bar.

In general, although Theo employed a double number line instead of a percentage bar, he showed his understanding of how to use the models as a tool in solving some percentage problem and noticed the reasoning behinds the bar (using anchor points as the intermediate steps). He was also aware of the relation among numbers in the double number line or in the percentage bar.

\section{CONCLUSION AND IMPLICATION}

a. Conclusion

The result of this study indicated that the sequence of lessons in this study can support students' understanding of percentages. Models, in this case bar model, can be beneficial for teachers to help students organize their ideas and build a deep understanding of math topics, such as percentages. A bar model is a fruitful model in which students can see the relation among numbers and use some intermediate steps to tackle percentages problems.

b. Implication

It is recommended for teachers to provide rich contexts in mathematics learning process, so students can explore many ideas behind the context. A rich context is also required to lead students to use models as a tool in understanding math topics and in solving math problems.

This study offers a set of instructional activities that can support students' learning. However, because of the limitation of time, there are only two lessons in this study. To strengthen students' understanding of percentages by using models, and the use of fractions and percentages to compare situations proportionally, the researcher recommends extending the lessons in future studies.

\section{REFERENCES}

Bakker, A., \& van Eerde, D. (2015). An Introduction to Design-Based Research with an Example From Statistics Education. https://doi.org/10.1007/97894-017-9181-6_16

Hawera, N., \& Taylor, M. (2011). Twenty Percent Free! So how much does the original bar weigh? Australian Primary Mathematics Classroom, 16(4), 3-7.

Heuvel-Panhuizen, M. Van Den. (2003). The didactical use of models in realistic mathematics education: An example from a longitudinal trajectory on percentage. Educational Studies in Mathematics.

Ningtyas, Y. D. W. K. (2014). Supporting 5th Grade Indonesian Students in Learning Percentages. Proceeding of the 2nd SEA $D R, 408-415$. Palembang.

Ningtyas, Y. D. W. K. (2016). Penggunaan Batang Persen untuk Menyelesaikan Permasalahan tentang Persen. Konferensi Nasional Penelitian Matematika Dan Pembelajarannya (KNPMP I) Universitas Muhammadiyah Surakarta, 469-476. Universitas Muhammadiyah Surakarta.

Parker, M., \& Leinhardt, G. (1995). Percent: A Privileged Proportion. Review of Educational Research, 65(4), 421-481. https://doi.org/10.3102/003465430650044 21

Reys, R., Lindquist, M. M., Lambdin, D.V. \& Smith, N., \& L. (2007). Helping Children Learn Mathematics. New Jersey: John Wiley \& Sons, Inc.

Rianasari, V. F., Budayasa, I. K., \& Patahuddin, S. M. (2012). Supporting students' understanding of percentage. Journal on Mathematics Education. https://doi.org/10.22342/jme.3.1.621.29-40

Sarumaha, Y. A., Putri, R. I. I., \& Hartono, Y. (2018). Percentage Bar: A Model For Helping Fifth Grade Students Understand Percentages. Mosharafa: Jurnal Pendidikan Matematika. https://doi.org/10.31980/mosharafa.v7i2.3 5 
van Galen, F., Feijs, E., Figueiredo, N., Solving problems with the percentage Gravemeijer, K., van Herpen, E., \& Keijzer, R. (2008). Relationships between fractions, percentages, decimals, and ratios. In Fractions, percentages, decimals and proportions: A learningteaching trajectory for grade 4, 5, and 6 . Rotterdam: Sense Publishers.

Van Galen, F., \& Van Eerde, D. (2013). 